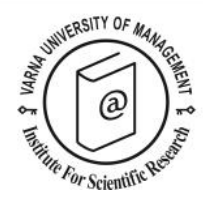

\title{
The impact of advertising creativity on purchase intention in the airline industry: A stimulus-organism-response (S-O-R) perspective
}

\author{
Ali Emre Sarılgan ${ }^{1}$, Şahap Akan ${ }^{2 *}$, Mahmut Bakır ${ }^{3}$ and Havane Süleç ${ }^{4}$
}

1 Eskisehir Technical University, Department of Aviation Management, 26470 Eskisehir, Turkey. E-mail: aesarilgan@eskisehir.edu.tr

2 Anadolu University, Department of Civil Aviation Management, 26210 Eskișehir, Turkey. E-mail: sakan@anadolu.edu.tr

3 Anadolu University, Department of Civil Aviation Management, 26210 Eskişehir, Turkey. E-mail: mahmutbakir@anadolu.edu.tr

4 Eskisehir Technical University, Department of Aviation Management, 26470 Eskisehir, Turkey. E-mail: havanesulec@eskisehir.edu.tr

${ }^{*}$ Corresponding author

\begin{abstract}
This study aims to understand the impact of advertising creativity on purchase intention in the airline industry. To this end, drawing on the Stimulus-Organism-Response (S-O-R) framework, the associations among advertising creativity, attitude toward advertising, flow experience, and purchase intention were investigated. Utilizing a total sample of 174 respondents in Turkey, the partial least squares structural equation modeling (PLS-SEM) approach was adopted to testing the research model. The results suggest that advertising creativity significantly affects purchase intention, attitude toward advertising, and flow experience. On the other hand, flow experience has no significant effect on purchase intention. Furthermore, attitude toward advertising mediates the relationship between advertising creativity and purchase intention.
\end{abstract}

Key words: Airline industry, S-O-R framework, Flow experience, Purchase intention, Social media advertising

Citation: Sarilgan, A.E., Akan, S., Bakır, M. and Süleç, H. (2022). The impact of advertising creativity on purchase intention in the airline industry: A stimulus-organism-response (S-O-R) perspective. European Journal of Tourism Research 30, 3014. 


\section{Introduction}

The advertising expenses of airlines have increased steadily in recent years. A study, conducted in the US, reported that the advertising expenditures of the airline industry were \$183.8 billion in 2019 (Statista, 2019). While this issue may be attributed to increased competition, it also results in consumers being exposed to more advertisements, thus meaning the existence of similar and immediately forgettable contents (Danaher \& Mullarkey, 2003). As such, some questions such as "Which features should advertisements have to stand out from their counterparts?" and "What kinds of advertising should be done?" have been raised by practitioners and researchers (Sameti \& Khalili, 2017). In this sense, it is worth examining how airline advertising can be more effective and drive consumers to purchase.

Airline advertisements should be catchy and distinguishable from their counterparts, and, in this regard, it is essential to include creative elements (Kim et al., 2016). Considering that creative advertisements are original, innovative, novel, and distinctive (El-Murad \& West, 2004), these characteristics can build positive cognitive and emotional perceptions in consumers and subsequently affect purchase intention/decision (Smith et al., 2008). When this process is considered within the framework of Stimulus-Organism-Response (S-O-R) (Mehrabian \& Russell, 1974), it can be built on the basis of a) exposure to creative advertisements, b) creating cognitive and emotional perceptions, and c) influencing the intention or decision. Accordingly, the S-O-R model establishes a ground to examine the effects of some cognitive and affective influences on a particular behaviour in a systematic manner (Moon et al., 2017).

The S-O-R model provides a useful account of how advertising creativity affects purchase intention. Although this relationship has been studied by many researchers in the extant literature (Idris et al., 2020; Sameti \& Khalili, 2017; Shirkhodaee \& Rezaee, 2014), no research has been found that surveyed the impact of advertising creativity on purchase intention in the airline industry. In fact, the effect of advertising creativity on purchase intention is related to the elaboration likelihood model (ELM). ELM is an important theory that explains that persuasion and attitude change processes take place in two different ways, namely central and environmental routes (Li \& Ito, 2021; Petty \& Cacioppo, 1986). The central route suggests that persuasion will occur as a result of careful examination of the core arguments of the message. Conversely, peripheral persuasion relies on environmental cues, such as the resource's being expert or attractive, rather than the strength of the argument conveyed by the messages (Cocolas et al., 2020). When moving from the central route to the peripheral route, individuals' involvement and information processing abilities decrease. In this regard, in air travel, which is a utilitarian and lowinvolvement product category, consumers may be more inclined to use the peripheral route for persuasion. Therefore, the effect of advertising creativity on the formation of consumers' attitudes as a peripheral cue on the peripheral route is worth exploring. However, the extant ELM research on the airline industry has been very limited (Fang et al., 2020; Li \& Ito, 2021). To bridge this gap in the literature, the present study aims to explore the impact of advertising creativity on purchase intention. This present study also posits the mediating role of attitude toward advertising and flow experience to build a bridge that links advertising creativity and purchase intention. In doing this, drawing on the S$\mathrm{O}-\mathrm{R}$ framework, we attempted to investigate the associations between advertising creativity, attitude toward advertising, flow experience, and purchase intention in airline advertising.

In this study, advertising creativity acted as a stimulus within the S-O-R model, whereas purchase intention was used as a response. Reviewing the literature on advertising creativity, many studies from other domains have focused on the associations between advertising creativity, attitude toward advertising, and purchase intention (Sameti \& Khalili, 2017; Shirkhodaee \& Rezaee, 2014; Smith \& Yang, 2004). Therefore, we considered attitude toward advertising as an organism in the context of airline 
advertising. On the other hand, although flow experience is an important antecedent of purchase intention (Martins et al., 2019; Yang et al., 2017), the impact of advertising creativity on flow experience has yet to be studied. Therefore, we suggested that flow experience be another organism to gain valuable insights.

To test the research model, this study focused on airline advertisements on social media platforms (e.g., Facebook, YouTube, Twitter, and Instagram) since airlines use social media extensively as a powerful marketing tool for engaging with current and potential customers, enhancing relationships, publicity, and promotion (Loo, 2020). SimpliFlying (2018) reported that $76 \%$ of executive-level managers agree that the importance of social media is increasing. Therefore, they allocate more budget for social media activities and expand their social media teams. In this regard, the most important budget item is advertising expenditures (40\% of the total social media budget) (SimpliFlying.com, 2018). There are some reasons behind the high advertising budgets in social media marketing (Sung et al., 2020). Social media advertising has the ability to instantly reveal consumer reactions by penetrating more people faster than traditional advertising (Lee \& Hong, 2016). Moreover, it can be argued that advertising efficiency is greatly improved in social media channels, especially since creative content has the potential to create viral effects (Berger \& Milkman, 2012). In this respect, social media platforms offer a unique outlet to run creative advertisements in the airline industry.

This study contributes to the literature in the following ways. To our knowledge, this study is the first attempt to investigate the impact of advertising creativity on purchase intention in the airline industry. Therefore, this research is expected to provide airline managers and advertisers with a deeper understanding of purchase intention formation by focusing on advertising creativity. It also extends the S-O-R model to the advertising creativity literature. Finally, this study highlights the impact of advertising creativity on flow experience. The remainder of the paper is structured as follows: Section 2 presents the theoretical background and hypotheses. Then, Section 3 explains the research method, and Section 4 presents the findings. Finally, Section 5 discusses the findings and concludes with the research limitations and avenues for future studies.

\section{Theoretical Background}

The S-O-R Model

Many studies have investigated environmental factors affecting consumers' emotions and consequently their behaviours. One of the basic models used to address this issue is the S-O-R model introduced by Mehrabian and Russell (1974). Mehrabian and Russell (1974) discussed the effect of environmental factors on consumer behaviours with the S-O-R model. The S-O-R model has a similarity to the information processing model in terms of explaining how the inputs in the external environment are processed in the cognitive systems of individuals and what kinds of output behaviours occur as a result (Zhu et al., 2020). The framework stands for the initials of stimulus, organism, and response words. This framework suggests that some environmental factors (stimulus) affect the individual's emotional and cognitive conditions (organism) and may cause a change in their behaviour (response) (Donovan \& Rossiter, 1982). This model also explains the interaction of the individual, situation, and decisionmaking.

Stimulus implies any factor that affects and stimulates the individual's internal state. Organism is the affective and cognitive condition caused by the stimulus. Lastly, response refers to the final outcome of consumers, which may emerge as an approach or avoidance behaviour (Moon et al., 2017). The existing literature indicates that the $\mathrm{S}-\mathrm{O}-\mathrm{R}$ framework has been used in many studies to elaborate on the various behaviours of customers (Cao \& Sun, 2018; Lu et al., 2018; Sohaib \& Kang, 2015). 


\section{Creative Advertising as Stimulus (S)}

Stimulus is an external influence that enables people to react by affecting their psychology (Namkung \& Jang, 2010). Stimulus is generally classified into two broader categories, namely: social-psychological stimulus and object stimulus. Social psychological stimulus originates from the environment of the individual, while object stimulus is related to complexity, time of consumption, and product-related features (Arora, 1982). Therefore, advertising creativity is considered to be an object stimulus since it includes the promotion of many features related to the product. Creative advertising provides businesses with a competitive advantage, it is a prerequisite of advertising effectiveness and facilitates the development of strong brands in the market (Triantos et al., 2010). Despite the importance of advertising creativity, there have been few academic studies until recently. In the 7os, the first examples in the related literature were conducted by advertising companies (Zinkhan, 1992). However, after the 9os, with the fact that advertisements had started to be more creative than before, the number of academic studies increased correspondingly (Reid et al., 1998).

Creativity is among the most complex human behaviours to be described (Al-Ababneh, 2020). Sternberg et al. (2010, p. 82) defined creativity as "the ability to produce work that is novel". Similarly, Reid et al. (1998, p. 3) defined creative advertising as "original and imaginative thought designed to produce goaldirected and problem-solving advertisements and commercials”. It is necessary to consider creative advertisements beyond an abstract definition so that they can be measured to judge their level of creativity. These measurable dimensions are novelty, resolution, elaboration, and synthesis. These dimensions serve as a guide for measuring the extent of the creativity of advertisements (White et al., 2002).

Many studies have been conducted on the effects of advertising creativity on consumer behaviours. Smith et al. (2008) suggested that creative advertisements attract consumers more. Singam et al. (2014) also emphasized that creative content makes it easier for consumers to remember the advertisement without any help. Dahlén et al. (2008) found that a creative advertisement can create positive thoughts for the brand even if it does not provide the basic benefits such as remembering, liking, or persuasion on the consumer. Over time, advertising creativity has attracted researchers and encouraged them to explore the relationship between advertising creativity and other pivotal advertising concepts, such as recall (Jin et al., 2019; Till \& Baack, 2005), liking (Dahlén et al., 2008; Stone et al., 2000), recognition (Stapel, 1998), and consumer attitude and purchase decision (Romoti-maniu \& Zaharie, 2014; Sameti \& Khalili, 2017).

\section{Attitude Toward Advertising and Flow Experience as Organisms (O)}

Organism is the recipient, which, after being stimulated, reacts consciously or unconsciously (Lu et al., 2018). In literature, the organism generally refers to consumers' affective and cognitive states. The affective state refers to the emotions of consumers exposed to the stimulus, whereas the cognitive state is everything that enters into the consumer's mind about the acquisition, retention, and retrieval of information (Loureiro et al., 2016). Thus, customers shape the decision processes by turning stimuli into meaningful information. In this study, the attitude toward advertising and flow experience are considered as organisms, and it is suggested that advertising creativity affects the affective and cognitive state of consumers (Famiyeh et al., 2018).

Csikszentmihalyi (1975, p. 36) defined flow as a "holistic sensation that people feel when they act with total involvement". Flow has also been interpreted as a loss of self-consciousness, a responsiveness to clear targets, passing the time faster than normal, and accepting related activity as a reward (Nakamura \& Csikszentmihalyi, 2014). The individual in the flow experience concentrates completely on the action 
he or she does, ignoring all the elements not related to the action. In the meantime, while the individual is experiencing flow experience, he has a complete sense of control over the activity. In literature, flow experience has been discussed in a wide range of studies including online games (Hsu \& Lu, 2004), sport (Jackson, 1996), website usage (Skadberg \& Kimmel, 2004), tourism (Chang, 2014), and social commerce (Liu et al., 2016). In a recent study, Martins et al. (2019) investigated the mediating effect of flow experience between advertising value and purchase intention in smartphone advertising.

Attitude toward advertising refers to a personal disposition that favourably or unfavourably responds to a particular advertising stimulus in case of exposure (Wahid \& Ahmed, 2011). Previous studies have discussed that consumer attitudes are an important element of social media advertising. Moreover, elements such as informativeness, entertainment, and irritation play a role in the formation of attitudes (Yang et al., 2017). Therefore, creativity in advertising that affects the personal disposition of individuals may also affect the attitude toward advertising. In that vein, attitude toward advertising has been operationalized as an organism in the literature (Moon et al., 2017; Sahoo \& Pillai, 2017).

\section{Purchase Intention as Response (R)}

According to the S-O-R model, responses affect the consumers' final decisions in accordance with cognitive and affective reactions. As a result, approach or avoidance behaviour arises (Moon et al., 2017). However, it is not easy to measure actual responses that reflect consumers' behaviour. At this point, as a valid predictor of behaviour ( $\mathrm{Lu}$ et al., 2018), behavioural intention is regarded as another way of measuring behaviour. Purchase intention reflects a subjective tendency of consumers to purchase products, and this only represents an important indicator of consumer behaviour (Zhu et al., 2020). Ingavale (2013) stated that exposure to a specific advertisement affects the purchasing behaviour of consumers. On the other hand, Jiang et al. (2010) stated that advertisements have some mental effects that direct consumers to a particular behaviour. Accordingly, conative responses such as purchase intention represent consumers' behavioural outcomes to these effects. Purchase intention refers to the likelihood of purchasing the relevant product or service in the future after exposure to the advertisement (Dodds et al., 1991). Since past studies have shown that purchase intention is the response of consumers to stimuli (Jiang et al., 2010; Liu et al., 2016), we considered purchase intention as a response in line with the extant literature (Liu et al., 2016; Moon et al., 2017; Sohaib \& Kang, 2015; Wu et al., 2019).

\section{Hypotheses Development}

The research model of this study, shown in Figure 1, is based on the S-O-R framework. As mentioned earlier, advertising creativity is used as an environmental stimulus, flow experience, and attitude toward advertising as cognitive organisms, and finally, purchase intention as a response.

Advertising creativity, which increases the effectiveness of advertisements, is related to how original and unexpected an advertisement is. Since creative advertisements are more prone to catch consumers' attention, they may affect the purchasing behaviour of consumers (Idris et al., 2020). In doing so, it strengthens purchase intention by affecting the awareness and beliefs of customers (Jovanovic et al., 2016). As such, we posit that advertising creativity positively affects consumers' purchase intention. In line with this argument, Modig and Rosengren (2014) stated that advertising creativity increases perceived product quality and perceived value and positively affects purchase intention. 


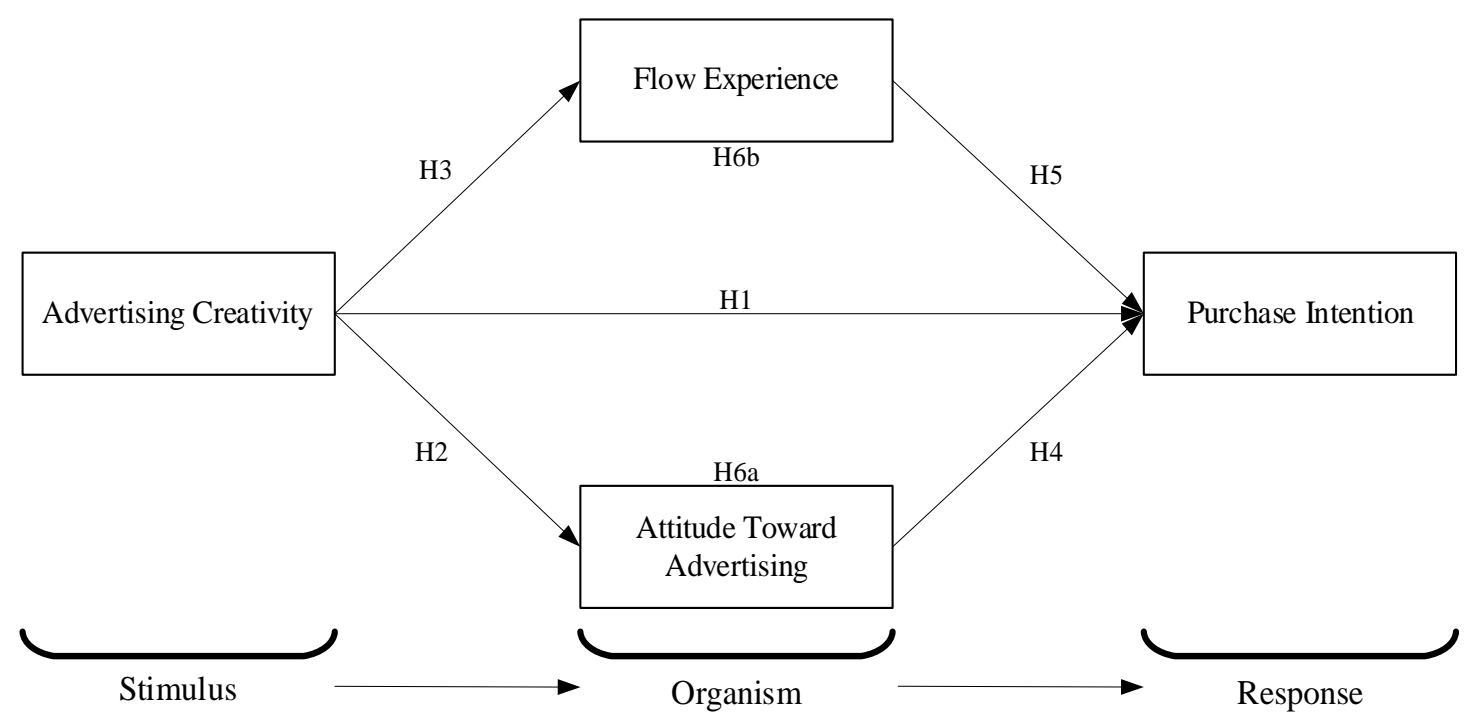

Figure 1. Research model

Similarly, Samuel and Aurellia (2017) found a direct effect of creative television advertising on purchase intention. In this study, purchase intention is considered as the intention of consumers to choose the relevant airline after exposure to creative advertisements. Therefore, in the context of the airline industry, this study hypothesized that:

H1. Advertising creativity has a positive impact on purchase intention.

Advertisements attract more attention owing to the element of creativity and increase the motivation of the consumers and create more positive attitudes (Smith et al., 2008). As per Ang and Low (2000), advertisements, which are found to be creative compared to regular advertisements, generate more favourable attitudes. Romoti-maniu and Zaharie (2014) also argued that advertising creativity is one of the antecedents that creates a positive attitude toward advertising because it provides an original and valuable message. Till and Baack (2005) revealed that creative advertisements enhance recall and attitude toward brand or product. Similarly, Sameti and Khalili (2017) stated that creative out-of-store advertising affects the attitude toward brand positively. Based on the above literature, we formulated the following hypothesis:

\section{H2. Advertising creativity has a positive impact on the attitude toward advertising.}

Creative advertisements are generally more noticeable (Stone et al., 200o). When interacting with creative content, consumers focus on advertisements and avoid some thoughts that can distract them (Hoffman \& Novak, 1996). Therefore, it can be suggested that creative advertisements foster flow experience. In line with this argument, Yang et al. (2017) suggested that the antecedents of flow experience should be carefully identified, and their effects on purchase intention should be revealed. In addition, Martins et al. (2019) found that entertainment-themed advertisements positively influence consumer flow experience. The above literature led to the following hypothesis:

H3. Advertising creativity has a positive impact on flow experience. 
The existing literature has revealed that the effect of attitude toward advertising on purchase intention arises in many ways, including the postulate of the attitude-intention-behavior path (Yang et al., 2017). From this perspective, Wahid and Ahmed (2011) found that the attitude toward advertising is positively and significantly associated with purchase intention. This relationship has also been drawn between consumers' attitudes toward creative advertising and purchase intentions. Shirkhodaee and Rezaee (2014) stated that creative advertisements have a positive effect on consumers' attitudes, which will favourably affect purchase intention. Moon et al. (2017) found that cognitive attitude and affective attitude have a significant effect on online purchase intention. Sameti and Khalili (2017) also argued that the attitude toward advertising affects purchase intention. Based on the above literature, the following hypothesis was established:

\section{H4. Attitude toward advertising has a positive impact on purchase intention.}

The existing literature has proposed many concepts, including flow experience (Martins et al., 2019), that may predict purchase intention (Jiang et al., 2010; Liu et al., 2016; Moon et al., 2017). In this sense, flow experience has many specific behavioural outcomes, such as purchase intention. Yang et al. (2017) specifically investigated consumers' perception of flow experience while they are watching online videos on YouTube. As a result of the study, they found that perceived flow significantly enhances purchase intention. Koufaris (2002) stated that consumers with flow experience are likely to make unplanned purchases. Focusing on Facebook games, Liu and Shiue (2014) also found that flow and price perception positively influence purchase intention. Therefore, the following hypothesis is proposed:

\section{H5. Flow experience has a positive impact on purchase intention.}

The S-O-R model has established that consumers' affective and cognitive states (organism) act as a mediator between stimuli and the final outcomes (response) (Liu et al., 2016). The mediating effect of flow experience and attitude towards advertising, which operate as organisms in this study, is well supported by the existing literature. Previous studies have suggested that, as an unexpected stimulus, creative advertisements can create emotional responses in consumers, lead to more favourable attitudes, and subsequently strengthen purchase intention (Sameti \& Khalili, 2017; Shirkhodaee \& Rezaee, 2014). Chinchanachokchai and de Gregorio (2020) proved the mediating role of attitude towards advertising between peer susceptibility and advertising avoidance in social media. Similarly, Zhao and Wang (2020) examined the indirect effect of advertising attitudes on the impact of perceived usefulness for short-video social network platforms on purchase intention. On the other hand, empirical findings have confirmed the mediating role of flow experience in social media research. Ameen et al. (2020) highlighted the mediating effect of flow between relationship commitment and shopping intention in their work. Liu et al. (2016) posited that flow experience in social shopping websites mediates the effect of interpersonal interaction factors on purchase intention. Recently, Hsu (2020) examined the indirect effect of flow experience on the relationship between parasocial interaction and sense of belonging. Based on the S-O-R model and previous studies, this current study suggests that attitude towards advertising and flow experience mediates the impact of creativity in airline advertising on purchase intention. Thus, we suggested the following hypotheses:

H6a. Attitude toward advertising mediates the relationship between advertising creativity and purchase intention.

H6b. Flow experience mediates the relationship between advertising creativity and purchase intention. 


\section{Research Methodology}

Sampling and Data Collection Process

People who have travelled by airline and have social media accounts in Turkey were constituted the target population of this study. Turkey is an important market where airline passenger traffic has increased by $\mathbf{2 5 4 . 2 8 \%}$ for the last ten years (World Bank, 2020). Furthermore, the social media penetration rate in Turkey is $70.8 \%$ of the total population (Kemp, 2021). Therefore, this paper has the potential to provide important insights from a market with a high rate of social media and airline usage.

Employing a convenience sampling method, a web-based survey instrument has been developed through Google forms. A pre-test was conducted on 29 respondents to ensure clarity and understandability of the items before the formal survey was carried out. The data collection process took place in November 2019. Despite the efforts to reach the participants through many online groups (via Facebook and WhatsApp), a total of 187 Turkish consumers received back. As a result of careful screening, suspicious responses such as straight-lining and zigzag patterns resulted in 174 usable questionnaires (Memon et al., 2019). To test whether these are sufficient to provide statistical power, a statistical power analysis was conducted (Hair et al., 2016). Through the G*Power 3.1 software, the minimum sample size required, for medium effect size $\left(f^{2}=0.15\right)$ and statistical power of 0.90 , was determined as 116 (Faul et al., 2007). Therefore, the final sample was considered to be sufficient for data analysis.

\section{Measurement}

All scales used in this study were taken from the past literature. Advertising creativity was adapted from Can and Macka (2016). In the creation of flow experience items, Martins et al. (2019) was used. The attitude toward advertising construct was adapted from Feng et al. (2016). Finally, purchase intention was measured by three items based on the scale of Martins et al. (2019). All constructs were structured with slight sectoral adaptations. Other constructs, except Can and Macka (2016), were translated into Turkish adopting back-translation procedures by two language experts. All construct items, which were measured on a five-point Likert scale (1 "strongly disagree" to 5 "strongly agree"), are shown in Table 3.

\section{Research Design and Method}

To examine the hypothesized relationships, partial least squares structural equation modeling (PLSSEM) was employed in this study. This technique can be considered to be a suitable choice from a variety of perspectives (Hair et al., 2016): a) it is preferred more than traditional multivariate approaches and is widespread, b) it aims to predict the relationships between latent variables in nature, c) it is effective in analyzing complex models with many latent and observed variables, d) it is flexible against minimum sample size and normality assumptions. The use of this approach is deemed sensible since this study is focused on the estimation of relationships rather than a theoretical validation. As such, SmartPLS v.3.2.8 and IBM SPSS Statistics 25 software were employed for the analyses.

\section{Data Analysis and Results}

Demographic Profile of Respondents

As shown in Table 1, among the 174 respondents who volunteered in the study, 99 (56.9\%) were female and $75(43.1 \%)$ were male. In terms of age, the largest portion was $16-25$ years $(66.1 \%)$, followed by 26 $35(24.7 \%), 36-45(5.7 \%), 46-60$ (2.9\%), and above 6o (o.6\%). For education, the majority of respondents had a bachelor's degree (72.4\%). On the other hand, only $3.4 \%$ of respondents did not attend high school education. Lastly, the average daily use of social media for most respondents was more than 2 hours to 4 hours $(42.5 \%)$. The second-largest group was 1 hour to 2 hours of social media use, constituting $29.3 \%$ of the respondents. 
When we compare the respondents' demographic profile and that of social media users in Turkey, we observe that they have similar characteristics. According to TurkStat (2020), higher educated individuals in Turkey has the highest internet usage rates. Moreover, the proportion of women in this segment is slightly higher than that of men. In terms of age groups, the largest portion in social media is 16-24 and then 25-34 years (Kemp, 2021; TurkStat, 2020). The fact that the average daily use of social media by Turkish consumers is 2 hours and 57 minutes confirms that we have a representative sample similar to the population of social media users (Kemp, 2021). In addition, we are also quite consistent with profiles that were used in similar studies on the Turkish airline industry. In previous studies, it has been observed that the airline consumer profile is mostly female, young, and highly educated (Ayodeji \& Rjoub, 2021; Kaya \& Gorkem, 2020; Șimșek \& Demirbağ, 2017).

Table 1. Respondent demographics

\begin{tabular}{llll}
\hline Demographic Variables & Item & Frequency & Percentage (\%) \\
\hline Gender & Male & 75 & 43.1 \\
& Female & 99 & 56.9 \\
\hline Age & $16-25$ & 115 & 66.1 \\
& $26-35$ & 43 & 24.7 \\
& $36-45$ & 10 & $5 \cdot 7$ \\
& $46-60$ & 5 & 2.9 \\
& $60+$ & 1 & 0.6 \\
\hline Education & Below High school & 6 & 3.4 \\
& High school & 25 & 14.4 \\
& Graduate & 126 & 72.4 \\
& Postgraduate & 17 & 9.8 \\
\hline Average daily & Less than 1 hour & 15 & 8.6 \\
social media usage & 1 hour to 2 hours & 51 & 29.3 \\
& More than 2 hours to 4 hours & 74 & 42.5 \\
& More than 4 hours & 34 & 19.5 \\
\hline
\end{tabular}

\section{Preliminary Analysis}

After finalizing demographic profiling, a preliminary analysis process was employed to check some issues such as data normality, linearity, and common method bias (Sarker et al., 2020). The data normality was checked by using skewness and kurtosis values with a threshold of \pm 2 (Nisar et al., 2021). In all constructs, the normal distribution assumption was met for skewness ranging from -0.773 to 0.346 and kurtosis ranging from -1.140 to 0.043. Ramsey's RESET test was also applied to detect nonlinear relationships (Sarstedt \& Mooi, 2019). The results showed that the relationships for the endogenous constructs of flow experience $[F(2,170)=1.505 ; p=0.225]$, attitude toward advertising $[F(2,170)=0.620$; $p=0.539]$, and purchase intention $[F(2,168)=0.221 ; p=0.802]$ are linear.

In this study, we presented a twofold approach to ensure that the common method bias (CMB) is not a serious threat. First, we employed the full collinearity test proposed by Kock (2017). As shown in Table 2, there is no serious CMB because variance inflation factors (VIFs) are less than 3.3 for all research constructs. We also conducted Harman's single factor test to verify this finding. As a result of the analysis, three factors existed, and the first general factor was account for less than $50 \%$ of the variance, thus showing that CMB is not a critical issue (Malhotra et al., 2017). 
Table 2. Full collinearity results

\begin{tabular}{lllll}
\hline & ADC & ATT & FE & PUI \\
\cline { 2 - 5 } Full Collinearity & 1.616 & 3.090 & 2.745 & 1.331 \\
\hline
\end{tabular}

Note. $\mathrm{ADC}=$ Advertising creativity, $\mathrm{ATT}=$ Attitude toward advertising, $\mathrm{FE}=$ Flow experience, and $\mathrm{PUI}=$ Purchase intention.

\section{Measurement Model}

The validity and reliability of the research model were tested using the measurement model (Hair et al., 2016). As seen in Table 3, the loading of all items exceeds the threshold of o.70 recommended by Hair et al. (2019). Similarly, average variance extracted (AVE) values are higher than the recommended value of 0.50 (Hair et al., 2016). Therefore, we concluded that convergent validity is achieved in the research model. In addition, Cronbach's Alpha $(\alpha)$ and composite reliability (CR) values for all constructs are significantly higher than 0.70 , thus indicating that the study constructs are quite reliable (Ali et al., 2018).

Table 3. Measurement items and analysis of measurement model

\begin{tabular}{lllll}
\hline Construct & Loading & Alpha & CR & AVE \\
\hline Advertising Creativity (ADC) & & 0.785 & 0.874 & 0.699 \\
\hline ADC1 Airline advertising is creative. & 0.846 & & & \\
ADC2 Airline advertisements are really extraordinary. & 0.796 & & & \\
ADC3 Airline advertisements are intriguing. & 0.863 & & & \\
\hline Attitude toward Advertising (ATT) & & 0.904 & 0.932 & 0.775 \\
\hline
\end{tabular}

ATT1 Using airline advertising is a good idea.

0.907

ATT2 I like the idea of watching airline advertisements. $\quad 0.894$

$\mathrm{ATT}_{3}$ I would be pleased to encounter airline advertisements 0.883 on social media.

$\mathrm{ATT}_{4}$ On the whole, my attitude toward airline advertising is positive.

Flow Experience (FE)

0.836

FE1 I am not distracted by other activities and stay focused on airline advertising.

FE2 I find myself eager to watch the advertising content of an airline company displayed on my smartphone.

FE3 I like to pay attention to airline advertising. $\quad 0.864$

Purchase Intention (PUI)

0.890

0.931

0.818

PUI1 I find flying with airlines advertised to be worthwhile. $\quad 0.914$

PUI2 I consider flying with the airline after I see its advertisements.

0.913

$\mathrm{PUI}_{3}$ I recommend the advertised airline company to others. 0.886

We also investigated discriminant validity through Fornell and Larcker's (1981) criterion. As Table 4 shows, discriminant validity was established since the correlation coefficients between constructs are smaller than the square root of the AVE of each construct. 
Table 4. Discriminant validity results

\begin{tabular}{lllll}
\hline Construct & ADC & ATT & FE & PUI \\
\hline ADC & 0.836 & & & \\
ATT & 0.602 & 0.880 & & \\
FE & 0.557 & 0.777 & 0.882 & 0.905 \\
PUI & 0.427 & 0.480 & 0.381 & \\
\hline
\end{tabular}

Note: Diagonals represent the square root of AVE and the correlation coefficients are given below the diagonal.

\section{Structural Model}

After ensuring the measurement model results, we evaluated the structural model. First, the significance of path coefficients was examined using a 5000 subsamples bootstrapping technique (Hair et al., 2019). Table 5 covers the path coefficients showing the hypothesized relationships. In addition, the results of the structural model are illustrated in Figure 2. As Table 5 depicts, advertising creativity has a positive effect on purchase intention $(\beta=0.221, p<0.01)$, attitude toward advertising $(\beta=0.602$, $p<0.01)$, and flow experience $(\beta=0.557, p<0.01)$, providing support for $\mathrm{H}_{1}, \mathrm{H}_{2}$, and $\mathrm{H}_{3}$. Likewise, the positive effect of attitude toward advertising on purchase intention was found to be statistically significant in $\mathrm{H}_{4}(\beta=0.370, p<0.01)$. On the other hand, $\mathrm{H}_{5}$, suggesting that flow experience has a positive effect on purchase intention, could not be supported $(\beta=-0.030, p=0.778)$.

To test H6a and H6b, we also employed a bootstrapping procedure-based mediation test with 5000 subsamples (Akkuş \& Arslan, 2021; Carrión et al., 2017). The significance of indirect effects depends on the fact that the confidence interval does not contain zero (Ameen et al., 2020). As seen in Table 5 , H6a confirmed the mediating effect of attitude towards advertising $(\beta=0.223, p<0.01,95 \% \mathrm{CI}[0.098 ; 0.348])$. On the other hand, we could not find support to accept H6b, which suggests the mediating effect of flow experience between advertising creativity and purchase intention $(\beta=-0.017, p=0.783,95 \%$ CI [$0,139 ; 0.101])$.

Table 5. Path coefficients and hypotheses decisions

\begin{tabular}{llllllll}
\hline & Path & $\begin{array}{l}\text { Std } \\
\text { beta }\end{array}$ & $\boldsymbol{t}$-value & $\boldsymbol{p}$-value & $\mathbf{9 5 \% \text { BCa CI }}$ & Decision & $\boldsymbol{f}^{2}$ \\
\hline $\mathrm{H} 1$ & ADC -> PUI & 0.221 & $\mathbf{2 . 7 2 7}$ & 0.006 & {$[0.050 ; 0.371]$} & Supported & 0.041 \\
$\mathrm{H} 2$ & ADC -> ATT & 0.602 & 13.246 & 0.000 & {$[0.498 ; 0.680]$} & Supported & 0.568 \\
H3 & ADC -> FE & 0.557 & 9.846 & 0.000 & {$[0.430 ; 0.652]$} & Supported & 0.449 \\
H4 & ATT -> PUI & 0.370 & 3.601 & 0.001 & {$[0.169 ; 0.567]$} & Supported & 0.066 \\
H5 & FE -> PUI & -0.030 & 0.282 & 0.778 & {$[-0.243 ; 0.176]$} & Rejected & 0.000 \\
\hline H6a & ADC -> ATT -> PUI & 0.223 & 3.478 & 0.001 & {$[0.098 ; 0.348]$} & Supported & \\
H6b & ADC -> FE -> PUI & -0.017 & 0.276 & 0.783 & {$[-0.139 ; 0.101]$} & Rejected & \\
\hline
\end{tabular}

Note. $\mathrm{BCa} \mathrm{CI}=$ Bias-corrected and accelerated confidence interval.

Next, the variance explained by attitude toward advertising, flow experience, and purchase intention was found to be $36.2 \%, 31 \%$, and $26.1 \%$, respectively (See Table 6 ). Although the $R^{2}$ value varies depending on the complexity of the model, values above 0.20 are generally accepted well in disciplines such as consumer behaviour (Hair et al., 2016; Rasoolimanesh et al., 2019). Therefore, we can conclude that the research model yields acceptable in-sample explanatory power. Using Cohen's (1992) effect size 
$\left(f^{2}\right)$ measure, we evaluated the effect of predictor constructs on endogenous constructs (Hair et al., 2016). The $f^{2}$ can be divided into three different categories depending on its severity: 0.02 (small effect), 0.15 (moderate effect), and 0.35 (large effect), respectively. The effect sizes shown in Table 5 are as follows: $\mathrm{H}_{2}\left(f^{2}=0.568\right)$ and $\mathrm{H}_{3}\left(f^{2}=0.449\right)$ paths provide large effect sizes, whereas $\mathrm{H}_{1}\left(f^{2}=0.041\right)$ and $\mathrm{H}_{4}$ $\left(f^{2}=0.066\right)$ paths have small effect sizes. Finally, using the blindfolding procedure, Stone-Geisser's $Q^{2}$ criterion was applied to measure the predictive accuracy of the model (Hair et al., 2019). As shown in Table 6, in-sample predictive relevance is established for all endogenous constructs since the $Q^{2}$ values are greater than zero.

Table 6. Results of $R^{2}$ and Stone-Geisser's $Q^{2}$ values

\begin{tabular}{lll}
\hline Construct & $\boldsymbol{R}^{2}$ & $\boldsymbol{Q}^{2}$ \\
\hline ATT & 0.362 & 0.265 \\
FE & 0.310 & 0.227 \\
PUI & 0.261 & 0.197 \\
\hline
\end{tabular}

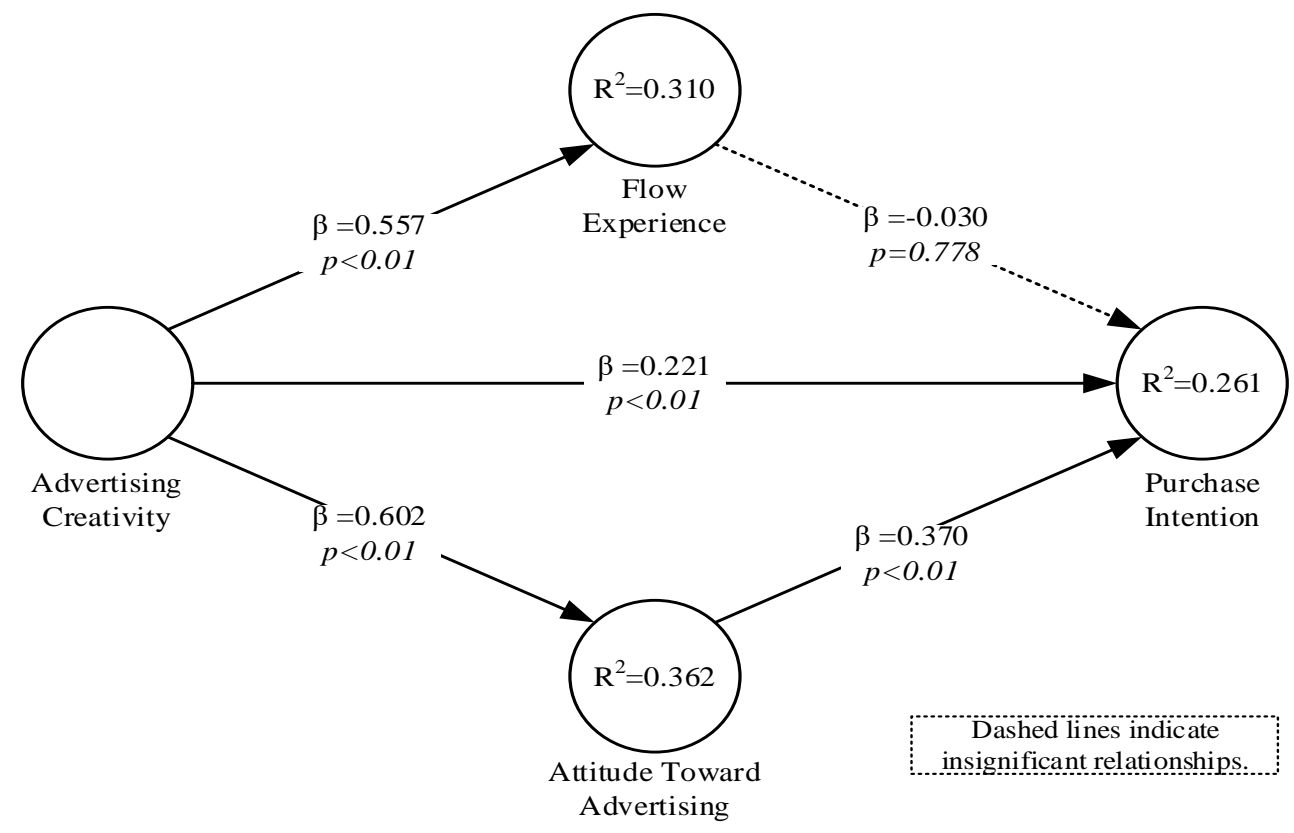

Figure 2. PLS-SEM results of the structural model

\section{Discussion and Conclusion}

Although the ultimate goal of advertising is to persuade consumers to buy the promoted brand, this goal is difficult to achieve. This is because consumers are exposed to too many advertisements, and reach to consumers' minds are getting so hard (Yang \& Smith, 2009). Advertising professionals and academicians consider advertising creativity to be a central element of effective advertising. Accordingly, many studies highlighted the importance of advertising creativity in consumer behaviour (Samuel \& Aurellia, 2017; Shirkhodaee \& Rezaee, 2014). However, to our knowledge, no study has shed light on the importance of advertising creativity in the airline industry. 
In this study, we investigated the impact of advertising creativity on purchase intention, building on the S-O-R model. The rationale of this study is that, according to the ELM literature, a peripheral cue such as advertising creativity has the potential to persuade airline customers to purchase. As such, the present study has proposed and tested a framework that examines the relationship between advertising creativity and purchase intention in the airline industry, using the mediating effect of attitude towards advertising and flow experience.

\section{Theoretical Implications}

This research draws several theoretical contributions to the related literature. First, advertising creativity significantly and positively affects purchase intention $(\beta=0.221, p<0.01)$. This finding is also in line with that of previous research from different domains (Modig \& Rosengren, 2014; Samuel \& Aurellia, 2017), which found that consumers who watch creative advertising have a higher purchase intention toward the products and services. Creative advertisements positively change the quality and value perceptions of consumers toward the product (Modig \& Rosengren, 2014). Subsequently, these changes in consumer perception can strengthen purchase intention and purchasing behaviour. Therefore, we conclude that creative advertisements have an increasing effect on consumers' purchase intention.

Second, advertising creativity positively and significantly affects the attitude toward advertising $(\beta=0.602, p<0.01)$. This finding is consistent with that of previous studies (Sameti \& Khalili, 2017; Smith et al., 2008; Till \& Baack, 2005). Customers can form good impressions about the product or brand by watching creative advertisements. In other words, when customers watch an advertisement with original, novel, and innovative features, they can develop a positive attitude toward the related product or brand. Indeed, Ang and Low (2000) argued that creative advertisements that are unexpected and have positive feelings can create more favourable attitudes than those of their less creative counterparts. Lee and Hong (2016) stated that creative advertising in social media channels increases the motivation to process the advertising, which subsequently improves attitudes towards advertising.

Therefore, it seems that consumer attitudes, the antecedent of many key elements, can be formed and enhanced through creative advertisements. Third, the relationship between advertising creativity and flow experience is significant $(\beta=0.557, p<0.01)$, thus indicating that advertising creativity is a pivotal predictor of flow experience. This result may be explained by the fact that creative advertisements lead to a stronger flow experience because they are attention-grabbing and distinctive. This finding contributes to the existing knowledge of flow experience by obtaining this relationship within the context of the airline industry.

Fourth, this study reveals a positive impact of attitude toward advertising on purchase intention $(\beta=0.370, p<0.01)$. This finding is also in line with that of past studies (Shirkhodaee \& Rezaee, 2014; Wahid \& Ahmed, 2011), which found that consumers with a positive attitude toward advertising have a higher intention to purchase the product as a result of the advertisement. Moreover, this result has been confirmed in the context of social media. Mukherjee and Banerjee (2019) reported the significant effect of attitude towards advertisements on purchase intention in the case of Facebook. Similarly, Zhao and Wang (2020) found that positive advertising attitude on short-video social network platforms reinforces the intention to purchase.

Lastly, as a contradictory result, no significant relationship was found between flow experience and purchase intention $(\beta=-0.030, p>0.778)$. In the existing literature, some studies confirmed this relationship (Koufaris, 2002; Yang et al., 2017), while others failed to exert this effect (D. Huang et al., 2017; Pu et al., 2015). For example, Koufaris (2002) found that flow experience affects intention to revisit 
online shopping stores. Cuevas et al. (2021) found that flow experience on Instagram will lead to increased purchase intention. Yang et al. (2017) stated that while watching videos online, being in a flow situation predicts the purchase intention and shopping behaviour. On the other hand, Huang et al. (2017) found that flow experience in the hotel booking process does not directly predict behavioural intention. Considering the airline industry context, airline travel purchasing behaviours differ from other purchasing behaviours in terms of several characteristics. Since air travel is a relatively expensive and time-consuming service, consumers need to make a rational assessment during decision-making. Therefore, consumers' intention to purchase may not increase despite being in a flow situation (Wu et al., 2014). Another possible explanation for this is that the relationship between flow experience and purchase intention may be mediated by other variables. Therefore, this present study may encourage researchers to understand the relationship between flow experience and purchase intention by looking from different perspectives.

Finally, the mediating roles are also worth examining. As predicted, research results confirmed that attitude towards advertising has a mediating role between advertising creativity and purchase intention $(\beta=0.223, p<0.01,95 \% \mathrm{CI}[0.098 ; 0.348])$. In other words, in line with past research (Zhao \& Wang, 2020), we highlighted the role of attitude toward advertising in enhancing purchase intention in the context of social media. On the other hand, although the past literature on social media established the mediating role of flow experience (Hsu, 2020; Ma et al., 2021), in this study, flow experience did not mediate the relationship between advertising creativity and purchase intention $(\beta=-0.017, p=0.783,95 \%$ CI [-0,139; 0.101]). This result may have resulted from the insignificant direct relationship between flow experience and purchase intention. The reason for the absence of this relationship is related to the peculiar characteristics of airline travel consumption, as mentioned earlier. As a result, the mediating effect of the flow posited in social media research in different fields was not observed in this study.

In general, the present research is the first study to examine the relationship between advertising creativity on social media and purchase intention in the airline industry, thus addressing a gap in the literature. Extending the S-O-R framework, it also contributes to our understanding of the associations between advertising creativity, the attitude toward advertising, flow experience, and purchase intention through a mediation model. In this regard, it is anticipated that it adds to the growing body of social media research in the airline industry (Loo, 2020; Tian et al., 2020).

\section{Practical Implications}

This study helps airline managers understand the formation of purchase intention through social media. Moreover, it broadens the understanding of creating persuasion and attitude change for airline consumers along the peripheral route. Accordingly, since advertising creativity significantly predicts purchase intention, advertisers and managers should seek ways to strengthen advertising creativity. This is especially important for the social media environment. Airlines rely on social media to stand out as the airline industry is more competitive today than ever before and they should, therefore, apply digital marketing strategies to attract existing and potential customers on social media to strengthen their position in the market and create brand loyalty. At this point, the creativity element is very important as it can attract customers and even turn them into real fans (Abhoulhosn, 2019).

This study also provides valuable insights into the mediating effect of attitude towards advertising. Accordingly, airlines should also strengthen the attitude towards advertising so that creative advertising lead to stronger purchase intention. The rapid development of technology changes consumer behaviour while shaping consumers' attitudes towards social media advertising. For example, Generation Z (or simply Gen Z) has different consumption patterns in the virtual environment as it grows in social media. 
One of the reflections of this is that they prefer short videos more. In this regard, airline managers should produce creative content in short advertisements to meet the demands of young consumers and strengthen their attitude towards advertising (Zhao \& Wang, 2020). This is a critical requirement because leading social media platforms such as Tiktok and Instagram support up to 15 seconds of video sharing. Therefore, the limited time is an important challenge against advertisements that will form creative and positive attitudes. In this regard, airline managers should take this constraint into consideration and focus on creating creative and interactive advertisements to grab consumers' attention (Shadani, 2020).

One unanticipated finding is that flow experience has no significant effect on purchase intention. A possible explanation for this might be that air travel decisions are costly and risky purchase decisions (Huang et al., 2010). Therefore, although creative advertisements boost flow experience, they may not lead to purchase intention in consumers. In this case, it may be recommended that airline managers and decision-makers use creative advertisements in promotions that will canalize consumers to impulse purchase behaviour without flow experience.

\section{Concluding Remarks}

Although this study offers valuable insights, it has a few limitations. First, the respondents were predominantly from a young-adult segment. Although the population characteristics are similar to those of general social media users, the generalizability of this study can be questioned. In future studies, a larger sample size should be considered to provide higher representation power. Second, being limited to airline consumers in Turkey, this study lacks the ability to reflect different countries and cultures. Since purchase intention is affected by cultural background (Rosillo-Díaz et al., 2020), further studies can be undertaken to explore how cultural background affects these relationships. Thus, possible similarities and differences between consumers in other countries and our sample can be understood. Third, this study covers the airline industry, which relies heavily on social media. In future research, the research model can be applied in domains such as tourism, e-commerce, luxury consumption, and certain brands. In addition, as discussed in Modig et al. (2014), the impact of advertising creativity on key outcomes such as brand interest and brand word of mouth (WOM) can be discussed.

\section{References}

Abhoulhosn, S. (2019). First Class Social Media Marketing For Airlines. http://blog.hellosocial.com.au/blog/social-media-marketing-for-airlines (Accessed on 15.10.2020).

Akkuş, G., \& Arslan, A. (2021). Intention to visit a destination from the perspective of Broken Windows theory. European Journal of Tourism Research, 28, 2802.

Al-Ababneh, M. M. (2020). The Concept of Creativity: Definitions and Theories. International Journal of Tourism \& Hotel Business Management, 2(1), 245-249.

Ali, F., Rasoolimanesh, S. M., Sarstedt, M., Ringle, C. M., \& Ryu, K. (2018). An assessment of the use of partial least squares structural equation modeling (PLS-SEM) in hospitality research. International Journal of Contemporary Hospitality Management, 30(1), 514-538. https://doi.org/10.1108/IJCHM-102016-0568

Ameen, N., Tarhini, A., Shah, M., \& Madichie, N. O. (2020). Going with the flow: smart shopping malls and omnichannel retailing. Journal of Services Marketing, (in press). https://doi.org/10.1108/JSM-022020-0066

Ang, S. H., \& Low, S. Y. M. (200o). Exploring the Dimensions of Ad Creativity. Psychology and Marketing, 17(10), 835-854. https://doi.org/10.1002/1520-6793(200010)17:10<835::aid-mar1>3.0.c0;2-\%23 
Arora, R. (1982). Validation of an S-O-R Model for Situation, Enduring, and Response Components of Involvement. Journal of Marketing Research, 19(4), 505-516. https://doi.org/10.2307/3151723

Ayodeji, Y., \& Rjoub, H. (2021). Investigation into waiting time, self-service technology, and customer loyalty: The mediating role of waiting time in satisfaction. Human Factors and Ergonomics In Manufacturing, 31(1), 27-41. https://doi.org/10.1002/hfm.20867

Berger, J., \& Milkman, K. L. (2012). What makes online content viral? Journal of Marketing Research, 49(2), 192-205. https://doi.org/10.1509/jmr.10.0353

Can, L., \& Macka, O. (2016). Sosyal Medya Reklamlarının Yaratıcılığının ve Reklama Yönelik Tutumun Satın Alma Niyetine Etkisi [The Effect of Social Media Advertisement Creativity and Attitude Toward Advertisement on Purchase Intention]. In A. Kayabaşı (Eds.), 21. Ulusal Pazarlama Kongresi [21st Marketing Congress]. Kütahya: Turkish National Marketing Association 137-147.

Cao, X., \& Sun, J. (2018). Exploring the Effect of Overload on the Discontinuous Intention of Social Media Users: An S-O-R Perspective. Computers in Human Behavior, 81, 10-18. https://doi.org/10.1016/j.chb.2017.11.035

Carrión, G. C., Nitzl, C., \& Roldán, J. L. (2017). Mediation Analyses in Partial Least Squares Structural Equation Modeling: Guidelines and Empirical Examples. In Hengky Latan \& R. Noonan (Eds.) Partial Least Squares Path Modeling: Basic Concepts, Methodological Issues and Applications. Cham: Springer International Publishing, 173-195. https://doi.org/10.1007/978-3-319-64069-3

Chang, K. C. (2014). Examining the Effect of Tour Guide Performance, Tourist Trust, Tourist Satisfaction, and Flow Experience on Tourists' Shopping Behavior. Asia Pacific Journal of Tourism Research, 19(2), 219-247. https://doi.org/10.1080/10941665.2012.739189

Chinchanachokchai, S., \& de Gregorio, F. (2020). A consumer socialization approach to understanding advertising avoidance on social media. Journal of Business Research, 110, 474-483. https://doi.org/10.1016/j.jbusres.2020.01.062

Cocolas, N., Walters, G., Ruhanen, L., \& Higham, J. (2020). Air travel attitude functions. Journal of Sustainable Tourism, 28(2), 319-336. https://doi.org/10.1080/09669582.2019.1671851

Cohen, J. (1992). A Power Primer. Psychological Bulletin, 112(1), 155-159. https://doi.org/10.1037/oo332909.112.1.155

Csikszentmihalyi, M. (1975). Beyond boredom and anxiety. San Francisco: Jossey-Bass Publishers.

Cuevas, L., Lyu, J., \& Lim, H. (2021). Flow matters: antecedents and outcomes of flow experience in social search on Instagram. Journal of Research in Interactive Marketing, (in press). https://doi.org/10.1108/JRIM-03-2019-0041

Dahlén, M., Rosengren, S., \& Törn, F. (2008). Advertising Creativity Matters. Journal of Advertising Research, 48(3), 392-403. https://doi.org/10.2501/Soo2184990808046X

Danaher, P. J., \& Mullarkey, G. W. (2003). Factors affecting online advertising recall: A study of students. Journal of Advertising Research, 43(3), 252-266. https://doi.org/10.1017/Soo21849903030319

Dodds, W. B., Monroe, K. B., \& Grewal, D. (1991). Effects of Price, Brand, and Store Information on Buyers' Product Evaluations. Journal of Marketing Research, 28(3), 307-319. https://doi.org/10.2307/3172866

Donovan, R., \& Rossiter, J. (1982). Store Atmosphere: An Environmental Psychology Approach. Journal of Retailing, 58(1), 34-57.

El-Murad, J., \& West, D. C. (2004). The Definition and Measurement of Creativity: What Do We Know? Journal of Advertising Research, 44(2), 188-201. https://doi.org/10.1017/Soo21849904040097

Famiyeh, S., Asante-Darko, D., \& Kwarteng, A. (2018). Service Quality, Customer Satisfaction, and Loyalty in the Banking Sector: The Moderating Role of Organizational Culture. International Journal of Quality and Reliability Management, 35(8), 1546-1567. https://doi.org/10.1108/IJQRM-o1-2017-00o8 
Fang, S., Zhang, C., \& Li, Y. (2020). Physical attractiveness of service employees and customer engagement in tourism industry. Annals of Tourism Research, 80, 102756 https://doi.org/10.1016/j.annals.2019.102756

Faul, F., Erdfelder, E., Lang, A. G., \& Buchner, A. (2007). G*Power 3: A Flexible Statistical Power Analysis Program for the Social, Behavioral, and Biomedical Sciences. Behavior Research Methods, 39(2), 175191. https://doi.org/10.3758/BFo3193146

Feng, X., Fu, S., \& Qin, J. (2016). Determinants of Consumers' Attitudes Toward Mobile Advertising: The Mediating Roles of Intrinsic and Extrinsic Motivations. Computers in Human Behavior, 63, 334-341. https://doi.org/10.1016/j.chb.2016.05.024

Fornell, C., \& Larcker, D. F. (1981). Evaluating Structural Equation Models with Unobservable Variables and Measurement Error. Journal of Marketing Research, 18(1), 39-50. https://doi.org/10.2307/3151312

Hair, J. F., Hult, G. T. M., Ringle, C. M., \& Sarstedt, M. (2016). A Primer on Partial Least Squares Structural Equation Modeling (PLS-SEM) (2nd ed.). Los Angeles: SAGE Publications, Inc.

Hair, J. F., Risher, J. J., Sarstedt, M., \& Ringle, C. M. (2019). When to use and how to report the results of PLS-SEM. European Business Review, 31(1), 2-24. https://doi.org/10.1108/EBR-11-2018-0203

Hoffman, D. L., \& Novak, T. P. (1996). Marketing in Hypermedia Computer-Mediated Environments: Conceptual Foundations. Journal of Marketing, 6o(3), 50-68. https://doi.org/10.2307/1251841

Hsu, C. L. (2020). How vloggers embrace their viewers: Focusing on the roles of para-social interactions and flow experience. Telematics and Informatics, 49, 101364. https://doi.org/10.1016/j.tele.2020.101364

Hsu, Chin Lung, \& Lu, H. P. (2004). Why do people play on-line games? An extended TAM with social influences and flow experience. Information and Management, 41(7), 853-868. https://doi.org/10.1016/j.im.2003.08.014

Huang, C. Y., Chou, C. J., \& Lin, P. C. (2010). Involvement theory in constructing bloggers' intention to purchase travel products. Tourism Management, 31(4), 513-526. https://doi.org/10.1016/j.tourman.2009.06.003

Huang, D., Li, Z., Mou, J., \& Liu, X. (2017). Effects of flow on young Chinese consumers' purchase intention: a study of e-servicescape in hotel booking context. Information Technology \& Tourism, 17, 203-228. https://doi.org/10.1007/s40558-016-0073-o

Idris, I., Xin, S. L. K., Alias, S. S., \& Ahmad, A. (2020). Factors that influence the effectiveness of online advertising in enhancing consumers' purchase intention among young adults in Malaysia. Test Engineering and Management, 82, 5528-5536.

Ingavale, D. R. (2013). Impact of Advertisements on Purchase Decision of Youth with reference to Consumer Goods. Advances in Management, 6(9), 36-40.

Jackson, S. A. (1996). Toward a conceptual understanding of the flow experience in elite athletes. Research Quarterly for Exercise and Sport, 67(1), 76-90. https://doi.org/10.108o/02701367.1996.10607928

Jiang, Z., Chan, J., Tan, B. C. Y., \& Chua, W. S. (2010). Effects of interactivity on website involvement and purchase intention. Journal of the Association for Information Systems, 11(1), 34-59. https://doi.org/10.17705/1jais.00218

Jin, H. S., Kerr, G., \& Suh, J. (2019). Impairment effects of creative ads on brand recall for other ads. European Journal of Marketing, 53(7), 1466-1483. https://doi.org/10.1108/EJM-10-2017-0674

Jovanovic, P., Vlastelica, T., \& Cicvaric Kostic, S. (2016). Impact of Advertising Appeals on Purchase Intention. Management - Journal for Theory and Practice of Management, 21(81), 35-45. https://doi.org/10.7595/management.fon.2016.0025

Kaya, L., \& Gorkem, S. Y. (2020). The effect of service quality, airline image, customer satisfaction and service value of passengers' behavioral intention: The case of Turkey. NEU Journal of Social Sciences, XIII(1), 50-66.

Kemp, S. (2021). Digital 2021: Turkey. https://datareportal.com/reports/digital-2021-turkey 
Kim, S., Kim, I., \& Hyun, S. S. (2016). First-Class in-Flight Services and Advertising Effectiveness: Antecedents of Customer-Centric Innovativeness and Brand Loyalty in the United States (US) Airline Industry. Journal of Travel \& Tourism Marketing, 33(1), 118-140. https://doi.org/10.1080/10548408.2015.1038420

Kock, N. (2017). Common Method Bias: A Full Collinearity Assessment Method for PLS-SEM. In H. Latan \& R. Noonan (Eds.) Partial Least Squares Path Modeling: Basic Concepts, Methodological Issues and Applications. Cham: Springer International Publishing, 215-257. https://doi.org/10.1007/978-3319-64069-3

Koufaris, M. (2002). Applying the Technology Acceptance Model and flow theory to online Consumer Behavior. Information Systems Research, 13(2), 205-223. https://doi.org/10.1287/isre.13.2.205.83

Lee, J., \& Hong, I. B. (2016). Predicting positive user responses to social media advertising: The roles of emotional appeal, informativeness, and creativity. International Journal of Information Management, 36(3), 360-373. https://doi.org/10.1016/j.ijinfomgt.2016.01.001

Li, S. R., \& Ito, N. (2021). "Nothing Can Stop Me!” Perceived Risk and Travel Intention Amid the COVID19 Pandemic: A Comparative Study of Wuhan and Sapporo. In W. Wörndl, C. Koo \& J. L. Stienmetz (Eds.), Proceedings of the ENTER 2021 eTourism Conference. Cham: Springer, 490-503. https://doi.org/10.1007/978-3-030-65785-7_47

Liu, H., Chu, H., Huang, Q., \& Chen, X. (2016). Enhancing the flow experience of consumers in China through interpersonal interaction in social commerce. Computers in Human Behavior, 58, 306-314. https://doi.org/10.1016/j.chb.2016.01.012

Liu, H. J., \& Shiue, Y. C. (2014). Influence of Facebook game players' behavior on flow and purchase intention. Social Behavior and Personality, 42(1), 125-133. https://doi.org/10.2224/sbp.2014.42.1.125

Loo, P. T. (2020). Exploring airline Companies' engagement with their passengers through social network: An investigation from their Facebook pages. Tourism Management Perspectives, 34, 100657. https://doi.org/10.1016/j.tmp.2020.100657

Loureiro, S. M. C., Koo, D. M., \& Ribeiro, L. (2016). Effects of atmospherics on emotions and intention with respect to involvement in different shopping environments. In G. Aiello, R. Donvito, \& T. Vescovi (Eds.) Global branding and country of origin: creativity and passion. London: Routledge, 79103. https://doi.org/10.108o/21639159.2013.82088o

Lu, Y., Qi, W., \& Qin, J. (2018). The research on wechat advertising effectiveness based on SOR model. CSAE'18: Proceedings of the 2nd International Conference on Computer Science and Application Engineering, 1-7. https://doi.org/10.1145/3207677.3278042

Ma, Y., Cao, Y., Li, L., Zhang, J., \& Clement, A. P. (2021). Following the flow: Exploring the impact of mobile technology environment on user's virtual experience and behavioral response. Journal of Theoretical and Applied Electronic Commerce Research, 16(2), 170-187. https://doi.org/10.4067/So71818762021000200112

Malhotra, N. K., Schaller, T. K., \& Patil, A. (2017). Common Method Variance in Advertising Research: When to Be Concerned and How to Control for It. Journal of Advertising, 46(1), 193-212. https://doi.org/10.108o/oog13367.2016.1252287

Martins, J., Costa, C., Oliveira, T., Gonçalves, R., \& Branco, F. (2019). How smartphone advertising influences consumers' purchase intention. Journal of Business Research, 94, 378-387. https://doi.org/10.1016/j.jbusres.2017.12.047

Mehrabian, A., \& Russell, J. A. (1974). An Approach to Environmental Psychology. Cambridge, Massachusetts: The MIT Press.

Memon, M. A., Cheah, J.-H., Ramayah, T., Ting, H., Chuah, F., \& Cham, T. H. (2019). Moderation Analysis: Issues and Guidelines. Journal of Applied Structural Equation Modeling, 3(1), i-xi. https://doi.org/10.47263/JASEM.3(1)o1 
Modig, E., Dahlén, M., \& Colliander, J. (2014). Consumer-perceived signals of 'creative' versus 'efficient' advertising: Investigating the roles of expense and effort. International Journal of Advertising, 33(1), 137-154. https://doi.org/10.2501/IJA-33-1-137-154

Modig, E., \& Rosengren, S. (2014). Can advertising creativity affect product perceptions and retailer evaluations? Journal of Product and Brand Management, 23(6), 452-461. https://doi.org/10.1108/JPBM-o6-2014-0651

Moon, M. A., Khalid, M. J., Awan, H. M., Attiq, S., Rasool, H., \& Kiran, M. (2017). Consumer's perceptions of website's utilitarian and hedonic attributes and online purchase intentions: A cognitive-affective attitude approach. Spanish Journal of Marketing-ESIC, 21(2), $\quad 73-88$. https://doi.org/10.1016/j.sjme.2017.07.001

Mukherjee, K., \& Banerjee, N. (2019). Social networking sites and customers' attitude towards advertisements. Journal of Research in Interactive Marketing, 13(4), 477-491. https://doi.org/10.1108/JRIM-o6-2018-0o81

Nakamura, J., \& Csikszentmihalyi, M. (2014). The concept of flow. In Mihaly Csikszentmihalyi (Ed.), Flow and the Foundations of Positive Psychology (pp. 239-263). Springer Netherlands. https://doi.org/10.1007/978-94-017-9088-8

Namkung, Y., \& Jang, S. C. (2010). Effects of perceived service fairness on emotions, and behavioral intentions in restaurants. European Journal of Marketing, 44(9), 1233-1259. https://doi.org/10.1108/03090561011062826

Nisar, Q. A., Haider, S., Ali, F., Naz, S., \& Ryu, K. (2021). Depletion of psychological, financial, and social resources in the hospitality sector during the pandemic. International Journal of Hospitality Management, 93, 102794. https://doi.org/10.1016/j.ijhm.2020.102794

Petty, R. E., \& Cacioppo, J. T. (1986). The elaboration likelihood model of persuasion. Advances in Experimental Social Psychology, 19(C), 123-205. https://doi.org/10.1016/Soo65-2601(o8)60214-2

$\mathrm{Pu}, \mathrm{W}$. P., Chen, K., \& Shieh, M. D. (2015). The effect of co-design and flow experience on customer satisfaction and purchase intention online. Issues in Business Management and Economics, 3(4), 5966. https://doi.org/10.15739/IBME.2014.015

Rasoolimanesh, S. M., Jaafar, M., Marzuki, A., \& Abdullah, S. (2019). Examining the effects of personal factors and travel characteristics on tourists' perceived crowding. European Journal of Tourism Research, 22, 5-19.

Reid, L. N., King, K. W., \& DeLorme, D. E. (1998). Top-level agency creatives look at advertising creativity then and now. Journal of Advertising, 27(2), 1-16. https://doi.org/10.108o/oo913367.1998.10673549

Romoti-maniu, A.-I., \& Zaharie, M.-M. (2014). Ambient advertising-the contextual influence on message perception. Romanian Journal of Marketing, 2, 45-50.

Rosillo-Díaz, E., Blanco-Encomienda, F. J., \& Crespo-Almendros, E. (2020). A cross-cultural analysis of perceived product quality, perceived risk and purchase intention in e-commerce platforms. Journal of Enterprise Information Management, 33(1), 139-160. https://doi.org/10.1108/JEIM-o6-2019-0150

Sahoo, D., \& Pillai, S. S. (2017). Role of mobile banking servicescape on customer attitude and engagement: An empirical investigation in India. International Journal of Bank Marketing, 35(7), 11131130. https://doi.org/10.1108/IJBM-09-2015-0144

Sameti, A., \& Khalili, H. (2017). Influence of in-store and out-of-store creative advertising strategies on consumer attitude and purchase intention. Intangible Capital, 13(3), 523-547. https://doi.org/10.3926/ic.986

Samuel, H., \& Aurellia, J. (2017). Ad-Creativity, Internal Consumer Response, and Purchase Intention: An Evaluation upon Ardiles "Flash Mom" TV Ad. International Conference on Communication and Media: An International Communication Association Regional Conference (i-COME’16), 33, 1-6. https://doi.org/10.1051/shsconf/20173300043 
Sarker, M., Mohd-Any, A. A., \& Kamarulzaman, Y. (2020). Validating a consumer-based service brand equity (CBSBE) model in the airline industry. Journal of Retailing and Consumer Services, 59, 102354. https://doi.org/10.1016/j.jretconser.2020.102354

Sarstedt, M., \& Mooi, E. (2019). A Concise Guide to Market Research: The Process, Data, and Methods Using IBM SPSS Statistics (3rd ed.). Berlin: Springer-Verlag GmbH.

Shadani, Z. (2020). Generation Z: How should brands target and engage them? https://gulfbusiness.com/generation-z-how-should-brands-target-and-engage-them/ (Accessed on 18.02.2021).

Shirkhodaee, M., \& Rezaee, S. (2014). The Power of Creative Advertising and Consumers' Perceived Risk. Journal of Promotion Management, 20(5), 590-6o6. https://doi.org/10.1080/10496491.2014.946209

SimpliFlying.com. (2018). Airline Social Media Outlook Report 2019. https://simpliflying.com/2018/airline-social-media-outlook-2019/

Şimşek, K., \& Demirbağ, O. (2017). Modeling Service Quality, Customer Satisfaction and Behavioral Intentions in Airline Industry: A SEM Approach. The Journal of International Scientific Researches, 2(6), 11-29. https://doi.org/10.23834/isrjournal.341694

Singam, G. D., Karunagaran, P., Pandiyan, T. S. D., Subramanian, T., \& Govindan, S. (2014). Creative advertising impact on customer acceptance of fast food restaurant. Academic Research International, 5(5), 308-318.

Skadberg, Y. X., \& Kimmel, J. R. (2004). Visitors' flow experience while browsing a Web site: Its measurement, contributing factors and consequences. Computers in Human Behavior, 20(3), 403422. https://doi.org/10.1016/So747-5632(03)00050-5

Smith, R. E., Chen, J., \& Yang, X. (2008). The impact of advertising creativity on the hierarchy of effects. Journal of Advertising, 37(4), 47-62. https://doi.org/10.2753/JOAoo91-3367370404

Smith, R. E., \& Yang, X. (2004). Toward a general theory of creativity in advertising: Examining the role of divergence. Marketing Theory, 4(1-2), 31-58. https://doi.org/10.1177/1470593104044086

Sohaib, O., \& Kang, K. (2015). Individual level culture influence on online consumer iTrust aspects towards purchase intention across cultures: A S-O-R model. International Journal of Electronic Business, 12(2), 142-161. https://doi.org/10.1504/IJEB.2015.069104

Stapel, J. (1998). Recall and recognition: A very close relationship. Journal of Advertising Research, 38(4), 41-45.

Statista. (2019). U.S. Scheduled Air Transportation Ad. Spend 2018-2020. https://www.statista.com/statistics/470564/scheduled-air-transportation-industry-ad-spend-usa/ (Accessed on 10.02.2021).

Sternberg, R. J., Jarvin, L., \& Grigorenko, E. L. (2010). Explorations in Giftedness. Cambridge: Cambridge University Press.

Stone, G., Besser, D., \& Lewis, L. E. (200o). Recall, liking, and creativity in TV commercials: A new approach. Journal of Advertising Research, 40(3), 7-16. https://doi.org/10.2501/jar-40-3-7-18

Sung, Y. H., Kim, D. H., Choi, D., \& Lee, S. Y. (2020). Facebook ads not working in the same way: The effect of cultural orientation and message construals on consumer response to social media ads. Telematics and Informatics, 52. https://doi.org/10.1016/j.tele.2020.101427

Tian, X., He, W., Tang, C., Li, L., Xu, H., \& Selover, D. (2020). A new approach of social media analytics to predict service quality: evidence from the airline industry. Journal of Enterprise Information Management, 33(1), 51-70. https://doi.org/10.1108/JEIM-03-2019-0086

Till, B. D., \& Baack, D. W. (2005). Recall and Persuasion: Does Creative Advertising Matter? Journal of Advertising, 34(3), 47-57. https://doi.org/10.108o/o0913367.2005.10639201

Triantos, A., Plakoyiannaki, E., \& Tsiotsou, R. (2010). Creativity in Social Advertising: Developing a Conceptual Framework. In L. Matei \& T. Dinu (Eds.), Proceedings of the gth International Congress 
of the International Association on Public and Non Profit Marketing. Bucharest: Editura Economică, 133-143.

TurkStat. (2020). Survey on Information and Communication Technology (ICT) Usage in Households and by Individuals, 2004-2020. https://data.tuik.gov.tr/Bulten/Index?p=Hanehalki-Bilisim-Teknolojileri(BT)-Kullanim-Arastirmasi-2020-33679 (Accessed on 01.03.2021).

Wahid, N. A., \& Ahmed, M. (2011). The effect of attitude toward advertisement on Yemeni female consumers' attitude toward brand and purchase intention. Global Business and Management Research: An International Journal, 3(1), 21-29.

White, A., Shen, F., \& Smith, B. L. (2002). Judging Advertising Creativity Using the Creative Product Semantic Scale. Journal of Creative Behavior, 36(4), 241-253. https://doi.org/10.1002/j.21626057.2002.tbo1067.x

World Bank. (2020). Air transport, passengers carried - Turkey. https://data.worldbank.org/indicator/IS.AIR.PSGR?locations=TR (Accessed on 10.02.2021).

Wu, C. H. J., Li, H. J., \& Chiu, C. W. (2014). Understanding consumer responses to travel websites from online shopping value and flow experience perspectives. Tourism Economics, 20(5), 1087-1103. https://doi.org/10.5367/te.2013.0326

Wu, C. H., Wang, W. R., Chen, Y. S., \& Juan, P. L. (2019). Applying the stimulus-organism-response model to consumer purchasing behavior in social commerce. Proceedings of the 2019 IEEE International Conference on Consumer Electronics. Yilan: Institute of Electrical and Electronics Engineers, 1-2. https://doi.org/10.1109/ICCE-TW46550.2019.8991879

Yang, K. C., Huang, C. H., Yang, C., \& Yang, S. Y. (2017). Consumer attitudes toward online video advertisement: YouTube as a platform. Kybernetes, 46(5), 840-853. https://doi.org/10.1108/K-032016-0038

Yang, X., \& Smith, R. E. (2009). Beyond attention effects: Modeling the persuasive and emotional effects of advertising creativity. Marketing Science, 28(5), 935-949. https://doi.org/10.1287/mksc.1080.0460

Zhao, J., \& Wang, J. (2020). Health advertising on short-video social media: A study on user attitudes based on the extended technology acceptance model. International Journal of Environmental Research and Public Health, 17(5), 1501. https://doi.org/10.3390/ijerph17051501

Zhu, L., Li, H., Wang, F. K., He, W., \& Tian, Z. (2020). How online reviews affect purchase intention: a new model based on the stimulus-organism-response (S-O-R) framework. Aslib Journal of Information Management, 72(4), 463-488. https://doi.org/10.1108/AJIM-11-2019-0308

Zinkhan, G. M. (1992). From the Editor: Topic Areas in the 'Journal of Advertising': 1973 through 1979. Journal of Advertising, 21(3), ii-ii.

Received: 30/12/2020

Accepted: 13/04/2021

Coordinating editor: Giacomo Del Chiappa 